\title{
TRIP TO BATU SECRET ZOO DAN PENGENDALIAN COVID-19
}

\section{TRIP TO BATU SECRET ZOO AND CONTROL OF COVID-19}

\section{Adiana Mutamsari Witaningrum¹, Umi Farichah Bascha², Dwi Setiani Sumardiko ${ }^{3}$, Dian Yuli Reindrawati ${ }^{4}$}

\author{
${ }^{1}$ Departemen Kesehatan Masyarakat Veteriner, Fakultas Kedokteran Hewan, Universitas \\ Airlangga \\ ${ }^{2,4}$ Program Studi D-III Manajemen Perhotelan Fakultas Vokasi, Universitas Airlangga \\ ${ }^{3}$ Program Studi D-III Pengobatan Traditional, Fakultas Vokasi, Universitas Airlangga \\ e-mail: adiana.mw@fkh.unair.ac.id
}

\begin{abstract}
The beginning of 2020, a new disease outbreak, namely Covid-19, has attack several countries around the world. The spread of this virus is very fast with a high mortality rate. Prevention efforts have been made by government to urging the public to carry out all activities from home and carry out outside activities by obey the rule with health protocols, such as wearing masks, washing hands and social distancing. Changes in people's behavior are require being able to adapt to new habits. This condition makes people feel bored with less varied routines. The community actually wants a refreshing in the middle of their routine during in pandemic. However, various tourism businesses that provide entertainment to release the boredom of community have also a significant impact with the Covid-19 outbreak. The government has advice for the temporary closure of tourist attractions during the pandemic and prepare adequate infrastructure for implementing health protocols when tourist attractions are reopened. The government has been suggestion to tourism businesses who are ready to receive tourists during the pandemic. This community service hope that the community will be wise in making travel decisions during the pandemic.
\end{abstract}

Keywords: Covid-19, Health Protocol, Prevention, Tourist Attraction

\section{abstrak}

Permulaan tahun 2020 muncul wabah penyakit baru yaitu Covid-19 yang melanda beberapa negara di seluruh dunia. Penyebaran virus ini sangat cepat dengan tingkat kematian yang cukup tinggi. Upaya penanggulangan telah dilakukan oleh pemerintah dengan menghimbau masyarakat untuk melakukan segala aktivitas dari rumah dan apabila melakukan aktivitas di luar rumah dengan memenuhi protokol kesehatan yaitu memakai masker, mencuci tangan dan menjaga jarak. Perubahan perilaku masyarakat menuntut untuk dapat beradaptasi dengan kebiasaan baru. Hal ini membuat masyarakat mengalami kejenuhan akan rutinitas yang kurang bervariasi. Masyarakat pun sebenarnya menginginkan adanya penyegaran di tengah rutinitas saat pandemi. Akan tetapi berbagai usaha wisata yang menyediakan hiburan untuk melepaskan kejenuhan yang dialami oleh masyarakat juga mengalami dampak yang signifikan dengan adanya wabah Covid-19 ini. Pemerintah menghimbau penutupan sementara tempat wisata selama pandemi dan mempersiapkan sarana prasarana yang memadai untuk penerapan protokol kesehatan saat tempat wisata dibuka kembali nantinya. Himbauan pemerintah telah dijalankan oleh pelaku usaha wisata yang siap menerima wisatawan saat pandemi. Dengan pengabdian masyarakat ini diharapkan masyarakat bijak dalam mengambil keputusan berwisata pada saat pandemi berlangsung.

Kata Kunci: Covid-19, Pengendalian, Protokol Kesehatan, Tempat Wisata

d

10.20473/jlm.v5i1.2021.1-8

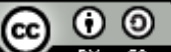

${ }_{\mathrm{EY}}$ Open acces under CC BY-SA license

Creative Commons Attribution-ShareAlike 4.0 International License 


\section{PENDAHULUAN}

Severe respiratory syndrome coronavirus 2 (SARS-CoV-2) merupakan virus yang menyebabkan penyakit Coronavirus Disease (Covid-19) seluruh dunia di tahun 2020 (World Health Organization, 2020). Penyebaran Covid-19 terjadi hampir di seluruh wilayah propinsi di Indonesia. Virus SARS-CoV-2 menyebar secara cepat dengan penularan dari manusia ke manusia yang menyebabkan gangguan pada sistem pernapasan hingga menyebabkan kematian. Gejala yang ditimbulkan yaitu batuk, demam, lemas, sesak napas, sakit tenggorokan, sakit kepala, keram otot, mual, sakit perut dan diare. Sedangkan kondisi penyerta pada penderita positif Covid-19 yaitu hipertensi, diabetes melitus, penyakit jantung, hamil, penyakit paru, penyakit ginjal, gangguan pernafasan, kanker, asma, gangguan imun, penyakit hati dan TBC (Komite Penanganan COVID-19 dan Pemulihan Ekonomi Nasional, 2020). Penyebaran Covid19 melalui kontak langsung dan terkena percikan dari batuk atau bersin penderita (Direktorat Jenderal Pencegahan dan Pengendalian Penyakit, 2020). Pengendalian penyebaran Covid-19 berdasarkan WHO dengan melakukan pembatasan aktivitas di luar rumah dan menggunakan protokol kesehatan seperti memakai masker, mencuci tangan dan menjaga jarak saat berada di luar rumah (World Health Organization, 2020).

Pembatasan aktivitas di luar rumah memberikan suatu adaptasi dengan lingkungan baru yang harus diterapkan masyarakat dimanapun keberadaannya. Covid-19 memberikan berbagai dampak di bidang kesehatan, ekonomi dan pariwisata. Indonesia kaya akan keindahan alam yang sangat diminati para wisatawan. Bepergian ke tempat wisata merupakan salah satu kegiatan yang dilakukan oleh masyarakat untuk melepaskan kejenuhan setelah melakukan aktivitas keseharian yang melelahkan. Dengan munculnya wabah Covid-19 memiliki dampak signifikan terhadap kunjungan ke tempat wisata. Di sisi lain masyarakat dikejutkan dengan kondisi beradaptasi dengan lingkungan baru yang membatasi kegiatan bepergian ke tempat wisata. Tempat wisata merupakan tujuan wisata yang memiliki daya tarik pada masyarakat untuk berkunjung. Daya tarik yang ditawarkan pada tempat wisata di Indonesia yaitu keanekaragaman budaya, kekayaan alam, dan hasil buatan manusia yang menjadi tujuan kunjungan masyarakat (Gunagama, 2020).

Pemerintah mengeluarkan keputusan mengenai penutupan sementara beberapa tempat wisata pada awal munculnya wabah Covid-19 untuk mengendalikan wabah Covid-19 menyebar secara meluas. Hal ini menyebabkan masyarakat yang mengalami tekanan pada masa sulit dalam menghadapi wabah Covid-19 dengan keterbatasan beraktivitas dan menyebabkan tingkat stres pada masyarakat meningkat. Kemudian pemerintah mengeluarkan peraturan Keputusan Menteri Kesehatan No. HK.01.07/MENKES/382/2020, tentang Protokol Kesehatan Bagi Masyarakat di Tempat dan Fasilitas Umum (Komite Penanganan Covid-19 dan Pemulihan Ekonomi Nasional, 2020), yaitu pengelola dihimbau untuk melakukan pembersihan secara berkala dengan mendisinfektan area, sarana dan peralatan yang terdapat di tempat wisata. Fasilitas cuci tangan dengan sabun yang memadai dan mudah diakses, mengecek suhu tubuh pengunjung di pintu masuk dan memperbanyak media informasi mengenai penerapan protokol kesehatan (Komite Penanganan Covid-19 dan Pemulihan Ekonomi Nasional, 2020).

Kunjungan ke berbagai tempat wisata merupakan salah satu kegiatan yang mulai ramai dikunjungi oleh para wisatawan setelah beberapa waktu lalu dilakukan penutupan sementara dikarenakan adanya pandemi yang disebabkan oleh Covid-19. Penutupan sementara merupakan upaya tempat wisata dalam persiapan penambahan sarana protokol kesehatan di wahana agar aman ketika para wisatawan saat berkunjung (Sugihamreta, 2020). 
Situasi Covid-19 masih dalam tingkat dengan risiko yang sangat tinggi di seluruh dunia. Oleh karena itu diperlukan adanya upaya pencegahan dan pengendalian untuk seluruh lapisan masyarakat agar tetap menjaga kesehatan, aman dan produktif. Segala upaya pencegahan dan pengendalian Covid-19 berdasarkan rekomendasi dari WHO dan menyesuaikan perkembangan Covid-19 (Kementerian Kesehatan RI, 2020).

\section{METODE PENGABDIAN MASYARAKAT}

Kegiatan pengabdian masyarakat yang telah dilaksanakan berdasarkan penelitian dan diskusi dengan pihak yang terkait yaitu warga masyarakat dan Batu Secret Zoo. Masalah yang sedang dihadapi masyarakat yaitu keinginan untuk berwisata dan terdapat kendala tidak dapat secara leluasa bepergian ke tempat wisata dikarenakan wabah Covid-19. Solusi yang diberikan dengan melaksanakan seminar nasional online yang memfasilitasi virtual trip ke Batu Secret Zoo dan penyuluhan mengenai pengendalian Covid-19.

Pengabdian masyarakat ini dilaksanakan dengan tahapan sebagai berikut: persiapan, pelaksanaan dan evaluasi. Tahap persiapan dengan membentuk panitia pelaksana, pembuatan proposal, survei lokasi pelaksanaan kegiatan, melakukan perijinan ke lokasi kegiatan dan membuat undangan serta pemberitahuan mengenai kegiatan kepada masyarakat di seluruh Indonesia.

Tahap pelaksanaan kegiatan dilakukan pada tanggal 20 September 2020, pukul 08.30 hingga 11.00 WIB melalui media Zoom yang diikuti oleh 126 peserta yang terdiri dari seluruh lapisan masyarakat dan distribusinya mulai anak-anak hingga dewasa. Kegiatan berlangsung dengan cara virtual trip di Batu Secret Zoo dan penyuluhan secara daring mengenai pengendalian Covid-19. Susunan acara meliputi registrasi peserta, pembukaan dan doa, menyanyikan Lagu Indonesia Raya, sambutan ketua pengabdian masyarakat, materi Virtual Trip Batu Secret Zoo, materi penyuluhan mengenai pengendalian Covid-19, sesi tanya jawab, kuis dengan media Kahoot, pemberian sertifikat dan penutupan.

Evaluasi akan pelaksanaan pengabdian masyarakat dilakukan dengan pengambilan data respons akan kegiatan yang telah dilakukan dengan mengirimkan Google form kepada peserta setelah mengikuti acara. Seminar nasional online ini juga memberikan doorprize kepada peserta yang menjadi pemenang kuis Kahoot yaitu pulsa, handsanitizer, minuman herbal, masker, kotak makan dan tumblr.

\section{HASIL DAN PEMBAHASAN}

Kegiatan pengabdian masyarakat yang dilaksanakan tanggal 20 September 2020. Peserta berjumlah 126 orang terdiri dari segala umur dan lapisan masyarakat yang ada di Indonesia. Waktu pelaksanaan dilaksanakan jam 08.30-11.00 WIB dengan menggunakan metode daring. 


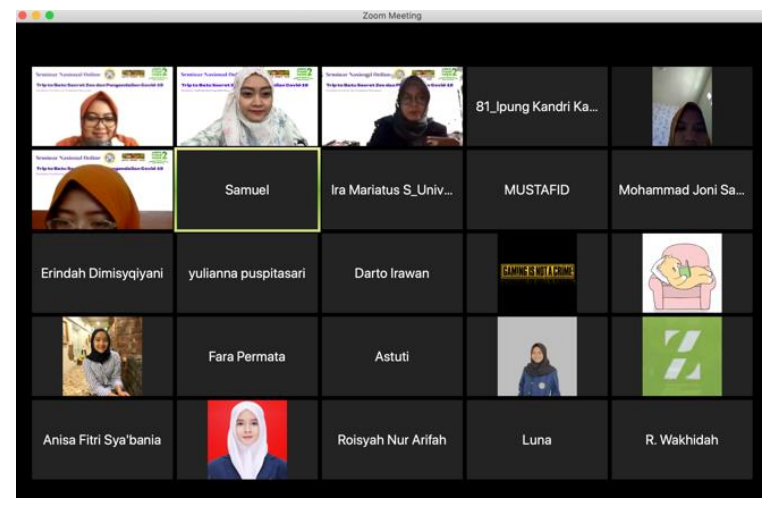

Gambar 1. Kegiatan Pengabdian Masyarakat secara Daring

Penyampaian materi mengenai virtual trip dilaksanakan dengan diawali prosedur pelaksanaan protokol kesehatan untuk wisatawan yang akan mengunjungi di Batu Secret Zoo dengan mencuci tangan, memasuki bilik disinfektan dan melakukan pemeriksaan suhu tubuh. Materi dilanjutkan dengan mengelilingi seluruh wahana yang ada di Batu Secret Zoo, antusiasme para peserta sangat tinggi dengan adanya berbagai komentar bahwa merasakan ingin ke Batu Secret Zoo secara langsung akan tetapi terhalang adanya Covid-19. Banyak para peserta yang merupakan anak-anak merasa senang dengan virtual trip ini dikarenakan menjadi hiburan di saat pandemi seperti ini.

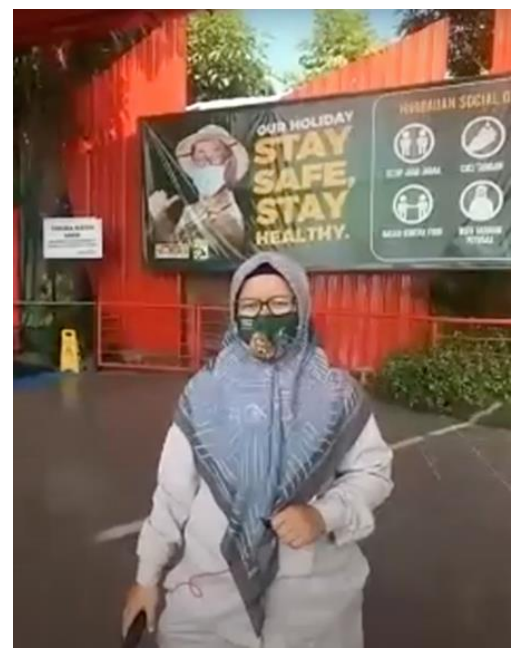

Gambar 2. Penyampaian Materi I Virtual Trip Batu Secret Zoo

Materi kedua merupakan penyampaian pengendalian Covid-19. Materi ini memberikan pengetahuan terhadap peserta mengenai apakah coronavirus, gejala yang timbul saat terpapar Covid-19, cara penyebaran dari Covid-19, pemahaman protokol kesehatan, hubungan antara Covid-19 dan hewan. Dengan penyampaian materi ini masyarakat menjadi lebih memahami mengenai virus Covid-19, gejala yang ditimbulkan setelah terpapar virus Covid-19 dan cara penyebarannya serta protokol kesehatan yang harus diterapkan saat berada diluar rumah umumnya dan berada di tempat wisata khususnya. Peserta juga menambah pengetahuan mengenai hubungan Covid-19 dengan hewan. 


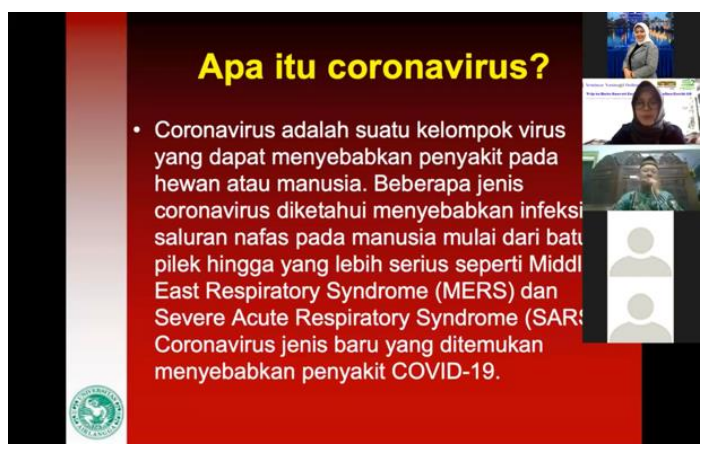

Gambar 3. Penyampaian Materi II Pengendalian Covid-19

Pengabdian masyarakat ini memberikan pengetahuan serta pemahaman yang dibutuhkan oleh masyarakat mengenai situasi pandemi Covid-19. Untuk mengetahui pemahaman yang telah diserap oleh masyarakat dilakukan kuis dengan menggunakan media Kahoot. Kuis ini diikuti oleh 62 peserta, dikarenakan jaringan yang tidak lancar sehingga tidak semua peserta dapat mengikuti kuis ini.

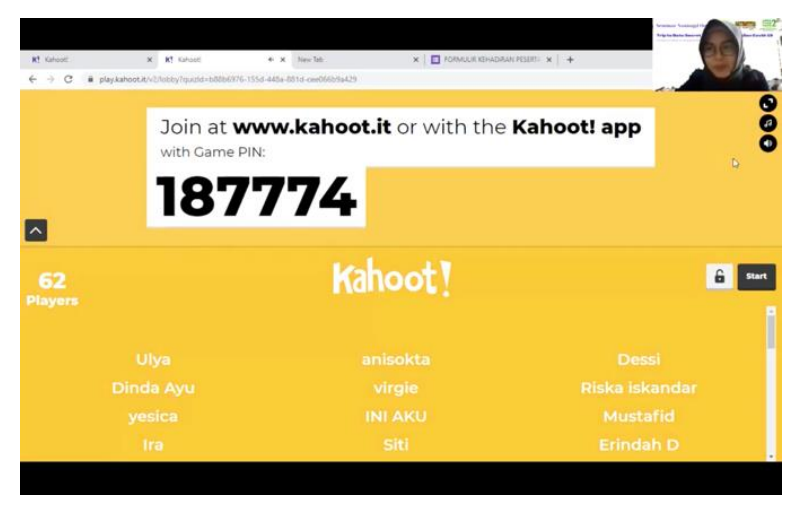

Gambar 4. Kuis Kahoot

Para peserta yang telah menjawab dengan benar dan menjadi pemenang sesuai urutan nilai yang didapat diberikan doorprize yaitu sanitizer dan herbal kit, yang dimaksudkan agar masyarakat menyadari akan pentingnya menjaga diri dengan pematuhan protokol kesehatan dan meningkatkan imun dengan meminum asupan vitamin yang diperlukan tubuh saat pandemi sehingga dapat beraktivitas dengan baik.

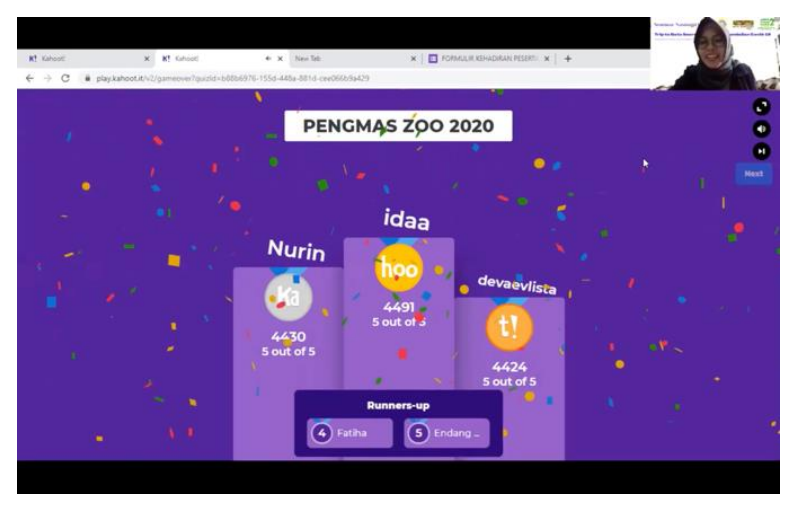

Gambar 5. Pemenang Kuis Kahoot yang Mendapatkan Doorprize 
Berdasarkan imbauan dari pemerintah dalam penanggulangan wabah Covid-19 yaitu work from home dan learn from home maka terjadi pembatasan ruang gerak masyarakat dengan interaksi di luar rumah. Masyarakat yang pada awalnya leluasa melakukan segala aktivitas baik bekerja, menuntut ilmu bahkan melepaskan penat dengan bepergian ke tempat wisata menjadi tidak bisa menjalankan aktivitas tersebut. Peningkatan kesadaran masyarakat akan pelaksanaan protokol kesehatan sangat penting saat pandemi seperti ini untuk meminimalkan penyebaran virus Covid-19. Aktivitas bekerja, belajar dan menikmati hiburan di dalam rumah selama masa pandemi berlangsung membuat terkadang kejenuhan pada masyarakat. Sehingga pada kegiatan pengabdian masyarakat ini kami menampilkan virtual trip pada salah satu tempat wisata yaitu Batu Secret Zoo yang telah memfasilitasi protokol kesehatan.

Kegiatan memiliki respons data dari 126 peserta yang merasa puas akan adanya virtual trip pada pengabdian masyarakat ini sebesar $92,6 \%$, sisanya $7,4 \%$ menyatakan bahwa kurang puas dikarenakan menginginkan secara langsung dapat menikmati wahana wisata akan tetapi wabah Covid-19 masih ada.

\section{Apakah Anda merasa puas dengan virtual trip ke tempat wisata kali ini? 122 responses}
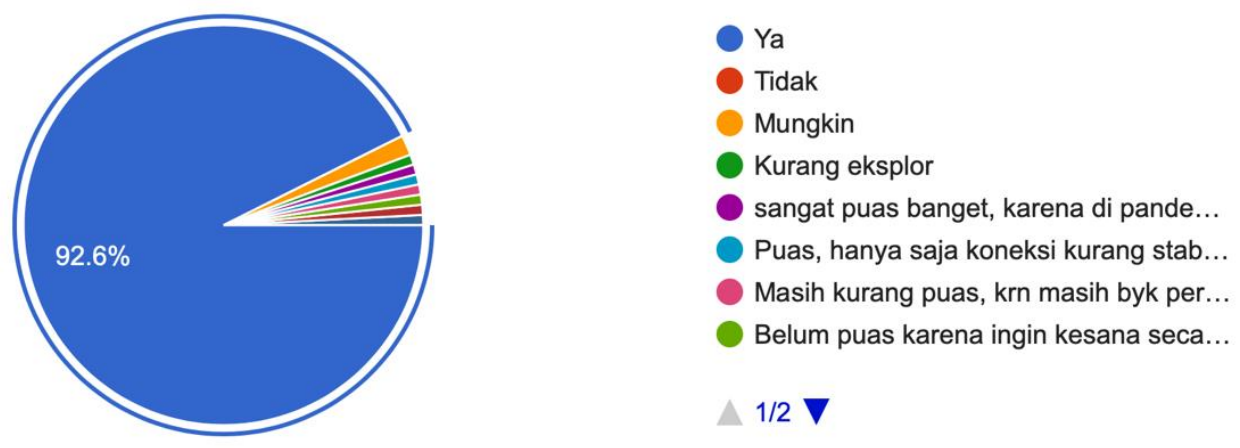

Gambar 6. Hasil survei tentang kepuasan pada kegiatan pengabdian masyarakat

Masyarakat menyampaikan $89,3 \%$ perlunya diadakan kegiatan virtual trip yang dapat mengobati rasa ingin berwisata yang terbatasi karena adanya Covid-19. Masyarakat mengharapkan kegiatan kunjungan ke tempat wisata lainnya.

Menurut Anda perlukah sering diadakan virtual trip seperti ini? 122 responses
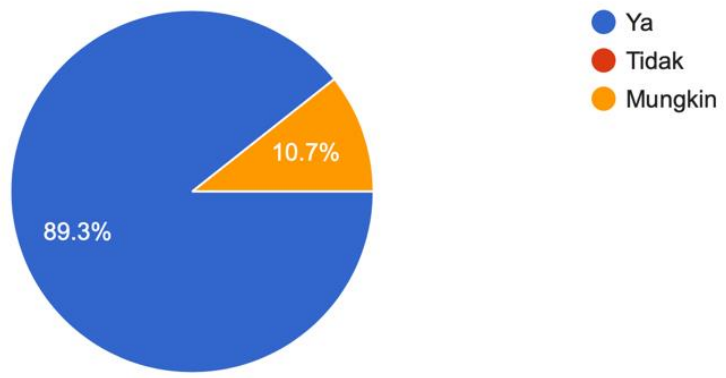

Gambar 7. Hasil survei tentang perlunya dilakukan virtual trip di berbagai tempat wisata 
Kegiatan ini memberikan edukasi dan pengalaman baru bagi masyarakat untuk dapat berwisata secara online agar masyarakat memperoleh penyegaran setelah menjalankan aktivitas seharihari dan menambah wawasan mengenai pengendalian Covid-19.

\section{PENUTUP}

\section{Simpulan}

Kegiatan pengabdian masyarakat yang dilaksanakan secara daring mendapatkan respons yang baik dari para peserta. Antusiasme masyarakat dalam mengikuti kegiatan ini sangat besar untuk penambahan pengetahuan mengenai pengendalian Covid-19 dan melakukan wisata secara daring. Peningkatan kesadaran akan penerapan protokol kesehatan sangat penting untuk pengendalian Covid-19 dan virtual trip memberikan penyegaran untuk masyarakat yang merasa penat dengan kegiatan selama pandemi berlangsung. Kegiatan ini diharapkan dapat berlangsung di lain waktu untuk memberikan pelayanan kepada masyarakat di saat pandemi.

\section{Saran}

Pengabdian masyarakat dalam hal virtual trip ke tempat wisata sangat dibutuhkan oleh masyarakat untuk dapat menghilangkan kejenuhan dalam menghadapi aktivitas pada masa pandemi Covid-19. Kegiatan ini dapat dilakukan secara berkesinambungan sehingga masyarakat masih dapat menikmati suasana dari tempat wisata secara online dan memberikan dampak positif menghilangkan stres yang dirasakan oleh masyarakat dan terpenuhi rasa ingin berwisata pada saat pandemi ini.

\section{Ucapan Terima Kasih}

Terima kasih kepada Lembaga Penelitian dan Inovasi Universitas Airlangga yang memberikan bantuan pendanaan pengabdian masyarakat sesuai dengan Surat Keputusan Ketua Lembaga Penelitian dan Inovasi Universitas Airlangga Nomor: 664/UN3.14/PT/2020 tanggal 20 Mei 2020 sehingga kegiatan seminar nasional online ini dapat berlangsung dengan baik dan kepada narasumber yang telah bersedia mengisi kegiatan seminar nasional online.

\section{DAFTAR PUSTAKA}

Direktorat Jenderal Pencegahan dan Pengendalian Penyakit. 2020. Pedoman pencegahan dan pengendalian Coronavirus Disease (Covid-19). Jakarta

Gunagama, MG. 2020. "Pariwisata Pasca pandemi: Pelajaran Penting dan Prospek Pengembangan". LOSARI : Jurnal Arsitektur, Kota dan Permukiman Vol. No.2 Agustus 2020 P-ISSN 2502-4892 E-ISSN 2527-8886

Kementerian Kesehatan RI. 2020. Pedoman Pencegahan dan Pengendalian Coronavirus Disease (Covid-19). Jakarta

Komite Penanganan COVID-19 dan Pemulihan Ekonomi Nasional. 2020. Peta Sebaran. Available from: https://covid19.go.id/peta-sebaran

Komite Penanganan COVID-19 dan Pemulihan Ekonomi Nasional. 2020. Pengelola dan Pengunjung Wisata Wajib Menerapkan Protokol Kesehatan Selama Pandemi COVID19. Available from https://covid19.go.id/p/berita/pengelola-dan-pengunjung-wisatawajib-menerapkan-protokol-kesehatan-selama-pandemi-covid-19 
Komite Penanganan COVID-19 dan Pemulihan Ekonomi Nasional. 2020. Regulasi. Available from $\quad$ https://covid19.go.id/p/regulasi/keputusan-menteri-kesehatan-nomor$\underline{\text { hk0107menkes } 3822020}$

Sugihamreta, IDG. 2020. "Respons Kebijakan: Mitigasi Dampak Wabah Covid-19 Pada Sektor Pariwisata". The Indonesian Journal of Development Planning. Volume IV No. 2.

World Health Organization. 2020. WHO Coronavirus Diseases (COVID-19) Dashboard. Available from: https://covid19.who.int/table

World Health Organization. 2020. Coronavirus disease (COVID-19) advice for the public. Available from: https://www.who.int/emergencies/diseases/novel-coronavirus2019/advice-for-public 